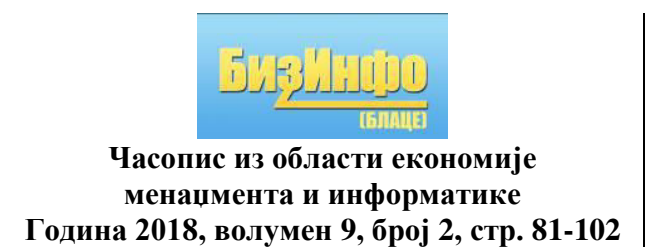

Година 2018, волумен 9, број 2, стр. 81-102

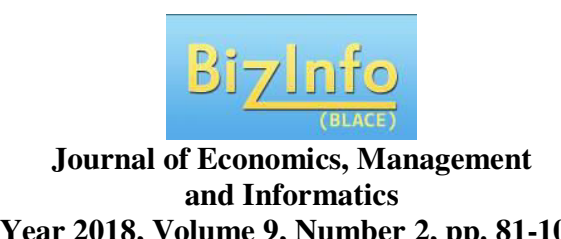

Year 2018, Volume 9, Number 2, pp. 81-102

\author{
Стручни рад/ Professional paper \\ УДК/UDC: 005.574:338.48]:004.738.5 \\ 004.738 .5
}

doi: 10.5937/bizinfo1802081S

\title{
THE IMPACT OF MEDIA CONVERGENCE ON THE DEVELOPMENT OF INTEGRATED CORPORATE COMMUNICATION IN TOURISM
}

\section{UTICAJ KONVERGENCIJE MEDIJA NA RAZVOJ INTEGRISANE KORPORATIVNE KOMUNIKACIJE U TURIZMU}

\author{
Branislav Sančanin ${ }^{1}$ \\ Ph.D. Student, University of Kragujevac, Faculty of Hotel Management and \\ Tourism, Vrnjci Spa
}

\begin{abstract}
Media convergence is reflected in the permeation and integration of various media and tourism activities, which increasingly alter the role and habits of identified target groups in tourism. The subject of this paper is research into the correlation between media convergence and growth and tourism development, through influence on corporate culture, identity, image and reputation which, within the broader context, has significant implications for integrated business communication in tourism. The aim of the paper is to point to the necessity of accelerating the grouping of integrated business communication in tourism within frameworks determined by media convergence. Considering the fact that media convergence is a process, just like the growth and development of tourism, this paper points to the technological, economic, social, cultural and global impact of convergence on traditional media, as well as on web and mobile content and their synergistic reflection on tourism. The influence of media convergence on growth and tourism development is subject to constant quantitative and qualitative changes, resulting in numerous internal and external determinants.
\end{abstract}

Key words: media convergence, new media, Internet, tourism

\footnotetext{
${ }^{1}$ branislav.sancanin@sbb.rs
} 
Rezime: Konvergencija medija ogleda se u prožimanju i integraciji različitih medija $i$ turističkih aktivnosti, koje sve više menjaju ulogu $i$ navike identifikovanih ciljnih grupa u turizmu. Predmet rada je istraživanje korelacije između konvergencije medija i rasta i razvoja turizma, kroz uticaj na korporativnu kulturu, identitet, imidž i reputaciju, što posmatrano u širem kontekstu naročito značajne implikacije ima na integrisanu poslovnu komunikaciju u turizmu. Cilj rada je da se ukaže na neophodnost ubrzanijeg grupisanja aktivnosti integrisanih poslovnih komunikacija $u$ turizmu $u$ okvirima koje determiniše konvergencija medija. S obzirom na to da konvergencija medija predstavlja proces, baš kao i rast i razvoj turizma, $u$ radu se ukazuje na tehnološki, ekonomski, društveni, kulturni i globalni uticaj konvergencije na tradicionalne medije, kao $i$ na web $i$ mobilne sadržaje $i$ njihovu sinergijsku refleksiju na turizam. Uticaj konvergencije medija na rast $i$ razvoj turizma podložan je stalnim kvantitativnim $i$ kvalitativnim promenama, što je rezultanta brojnih internih i eksternih determinanti.

Ključne reči: konvergencija medija, novi mediji, internet, turizam

\section{INTRODUCTION}

In a highly dynamic environment, media convergence is recognized as a thoughtful, organized and measurable knowledge-based basic instrument, with numerous positive implications, which can contribute to the growth and development of tourism.

Given that at the present, a detailed examination and an exact design of all relevant aspects of the tourism business system is being imposed as an imperative to development, an analysis of the impact of media convergence on the development of tourism is gaining in significance.

Media convergence ${ }^{1}$ no longer belongs to a distant and uncertain future, it is a present within which an increasing number of tourism companies and media organizations are working in, simultaneously. The integration and permeation of various media have changed their business philosophy, at its core, as well as bringing change to the overall organization, and manner, in which numerous tourism companies function during the process of creating and maintaining corporate culture, identity, image and reputation.

Integrated corporate communication forms the basis of corporate culture and corporate identity, which seeks to create a desired corporate image and reputation, thereby ensuring the organization's competitive positioning (Kostić-Stanković, 2011).

${ }^{1}$ lat. con + vergere $=$ to converge, to strive for the same goal 
If corporate communication is managed appropriately, it can have a significant impact on an organization's performance. In order to achieve this, it is essential for all elements of corporate communication to be integrated into one whole. Integration ensures the harmonization of symbols, messages and organizational behavior into a stable development platform. Integrated corporate communication provides trust among public target audiences (Kostić-Stanković, Todović, 2015).

Compared to all previously implemented novelties, media convergence, which is the result of the application of advanced multimedia communication $^{1}$, is one of the most significant turnarounds, not only in the production and distribution of tourist media content but also in relation to the consumer role. For this reason, dealing with this topic represents a need to point to new frameworks that have changed access to mass media, and which were previously viewed as separate platforms.

In following these changes, the necessity of continuous education has been imposed so as to enable managers in charge of corporate communication in tourism to be able to receive sufficient knowledge and skills, at any time, necessary for them to work in a convergent media environment.

The influence of media convergence on tourism development can be viewed from several aspects: technological, economic and journalistic. In this paper, special attention will be paid to the convergence of press, radio and television, since access to the media industry has reached a level of unrecognizability, when compared to the previous 5 to 10 years. The need for more managers from the tourism industry to become acquainted with media convergence is unavoidable in order for them to accept change, in terms of the simultaneous consequence that convergence produces on media and tourism activities, that is, on overall business activities. This is, viewed from the standpoint of tourist corporate communication, a kind of statement attesting to a readiness to accept the challenges that media convergence implies, as well as to the necessity for constant learning which will ensure stability during the development and management of new digital content, harmonizing the acquired experience with rapid changes in tourism and the media sphere.

When it comes to journalistic convergence, the process is analyzed within the context of utilizing all available media in order to maximize the use of their resources and ensure optimum use of multiplatform production, on the one hand, and a wide range of tourism media products, on the other.

${ }^{1}$ multimedia-lat $\cdot$ multus $=$ many + medium $=$ media 
In the future, the economic aspect of convergence could have a decisive role because the integration of different organizational and functional forms, into one common one, saves resources and significantly reduces business costs. The answer to the question of why it is important to utilize all benefits of media convergence in tourism is found in indicators that place tourism and travel into one of the world's largest economic sectors, employing one person for every 10 travelers, i.e., about 313 million jobs worldwide, and generating $10.4 \%$ of the global GDP (Travel \& Tourism Economic Impact 2016 World).

The topic of this paper has not been sufficiently explored thus it has increasingly become a subject of study and experience transfer. A demand for a multidisciplinary approach has been expressed, as confirmed by scientific literature and practitioners. Dynamic changes, user demands, and expectations indicate that the subject matter will be challenging for researchers, but never fully explored or with a clearly defined strategy that could satisfy the tourism audience.

\section{CONVERGENCE MODELS}

Companies, just like the media, are forced to use all available resources, bearing in mind that the center of the strategy is no longer individual channels and media, but a differentiated audience with their respective habits, needs and possibilities.

Jose Alberto Garcia-Aviles, a professor at Miguel Hernandez University's Journalism Department (Elche, Spain) and director of the doctoral program New Journalistic Models, conducted a research on convergence models in newsrooms in Austria, Spain and Germany. Three media convergence models were distinguished (Aviles et al. 2009).

Full integration: This integration marks a strategic commitment to integrating all platforms under one ownership. Priority is given to full integration, taking into account the necessity of training journalists for the multimedia production process.

For managers in charge of developing integrated corporate communication, integrated platforms are most favorable in tourism as they provide optimal conditions for immediate distribution of content intended for the media audience.

Cross-media: In this case, journalists are engaged in various editorial boards and work on different platforms but are nevertheless linked by a multimedia coordinator. These are cases where several platforms are engaged for the purpose of distributing media content. 
Cross-media does not provide direct distribution of media content, therefore managers responsible for enhancing integrated corporate communication in the tourist industry are given the task of offering the media, depending on the level of convergence, adequate content, ready to be offered to the broadest audience, with or without minimal adjustments.

Coordination of isolated platforms: An environment in which managers are not yet ready for changes that lead to a new organizational and functional structure is an area where the boundaries between online editions, press, radio and television are too far apart.

Isolated platforms impose numerous tasks for managers in charge of integrated corporate communication in the field of tourism, since it is necessary to create separate multimedia content for each individual media, that is, for all selected platforms.

\section{CONVERGENCE LEVELS}

The development of new technologies in the multimedia environment is unstoppable. We are constantly witnessing the creation of new content, the modification and upgrading of existing forms of mass communication, and content hyperproduction. It has been estimated that in the last three decades of the last century more information has been produced than in the previous five thousand years, that is, the weekly edition of the New York Times at the end of the 20th century contained more information than an educated person in the 18th century could accumulate throughout his/her life (Ramonet, 2001).

We cannot isolate different convergence levels from the development of integrated corporate communication in tourism. New technologies have definitely accelerated changes in media content as well as media organization.

Convergence has provided a new opportunity for the media to promote commonly accepted values and serve the public interest, while information technologies offer journalists the opportunity to subordinate their work, through flexibility and a wide range of topics, to the interests and needs of the broadest public.

By thoroughly and thematically encompassing the targeted audience, media convergence is a stable platform for the development of integrated corporate communication, developing its image and the way it is presented to the public, in the best way, as well as by creating a new, qualitatively different 
awareness of the company and its tourism products. The level of positive informativeness of the tourist target audience is in direct proportion to the undertaken scope and quality of corporate, and broader, business activities.

Another aspect of media convergence stands out, one that Jenkins identifies as one of its main disadvantages: for media convergence to encourage the audience to participate in the content creation process, it is necessary to ensure access to modern technologies, to be familiar with new media, and to secure the development of particular skills. From this it becomes clear that a certain segment of the tourist audience will remain neglected and that, due to a kind of "participation gap", it will not be able to fully participate in the new media culture (Jenkins, 2006). Nevertheless, convergence has brought tourists a sense of being creators in the media field, i.e., their direct participation being a powerful force, who demonstrate this feeling via textual and audio/video messages across the wide specter of web media platforms.

Changed media logic and Internet popularization have caused a number of structural changes to all parts of social life. The reflection of the resulting change is a convergence that is categorized, according to the simplest definition, as technological and media. Convergent communication channels affect the tourist recipients' perception. Media concentration changes the image of media space because it is based on the general interest of the audience and the reduction of costs, which affects the traditional aspects of journalism and relates to the integration and reorganization of the editorial board. Kalamar points out that technologies based on convergence are visible in the Slovenian media space, reflected in the changed production of media content and, accordingly, the reorganization of media organizations. These changes have created and continue to create new user experiences. Convergence thus refers to the social and cultural nature that triggers the question of the formation of a global village and the risk of cultural homogenization in an e-information society (Kalamar, 2016).

Within our region, the idea of media convergence, relating to radio, television and the Internet, was first promoted by the media house $\mathrm{B} 92^{1}$, one of the best examples being the show Kažiprst. This show was simultaneously broadcast on radio and television, being also available to users via podcasts, and finally in the form of a transcript on its website (Martinoli, 2011).

Many levels of convergence have been defined. One of the most appropriate approaches is one that classifies five levels of convergence (Jenkins, 2001):

- Technological convergence - we have attained technological convergence thanks to the digitization of media content. Despite

${ }^{1}$ TV B92 from September 11, 2017, renamed 02 TV 
differences, text, images and sound are presented in the same way by a digital key, and so they can move through different digital platforms.

- Economic convergence - indicates horizontal integration, which ensures the exploitation of content through different media. This implies the restructuring of complete production and, thanks to synergy, the creation of new, significantly higher values.

- Social or organic convergence - suggests that users in the digital environment develop the ability to perform multiple actions, simultaneously. A multitasking strategy indicates an occurrence where the user, simultaneously, watches a promotional television broadcast on a tourist destination, listens to music on the radio and sends text messages or e-mails.

- Cultural convergence - is a process during which users create different content and publish it on different platforms. This convergence represents a wide array of new forms of creativity at a crossroads of various media technologies, industries and consumers.

Media convergence encourages a new participatory culture in which an average person can receive tools for content recycling, marking and replying, as well as archiving.

This level of convergence imposes new expectations on companies towards the function of integrated corporate communication, as the generation of new cheaper content contributes to the general publics' greater awareness of all relevant information on a company, thus creating the desired image and reputation.

Global convergence - is reflected in the creation of cultural hybridization that is the result of international circulation of media content. It is these new forms of convergence that confirm the experience of working in a "global village".

Media convergence in a global, intercultural environment produces a range of social, economic, political and legal challenges, primarily because of the conflict between the goals of companies and those of the public. These contradictory forces encourage both cultural diversity and commercialization.

Certain conditions need to be met in order to ensure desired harmony between the convergent media environment and tourist activity, primarily through integrated corporate communication (Blek, 2003):

1. Complete and truthful information, which normally flows up, goes down and to the side; 
2. Trust between employer and employees;

3. Healthy and safe working conditions;

4. Fair payment of earnings;

5. Work continuity without conflict;

6. Employee satisfaction during the majority of his/her working hours;

7. Feeling proud of a company and having faith in the future.

\subsection{Internet}

The Internet has managed to surpass all thus far known media parameters: it does not have a spatial-temporal constraint, the hierarchical structure is loose, and there are no limitations in terms of themes, format and effects.

It allows direct access to information, provides a more attractive, innovative and visualized presentation of content and, especially important for tourism, ensures interaction and public involvement (e-mail, forums, blogs). The Internet has an informational, presentational, educational and entertaining role in real-time distribution.

The fact is that the Internet and digital technologies are rapidly changing the world. However, due to network barriers, certain services and products are not available to everyone equally, and companies that make their business online are faced with limitations that prevent them from taking advantage of all benefits digital tools have to offer. This is one of the most important reasons why the European Commission has started the process of adapting the single European Union market to the digital age, i.e., abolishing regulatory barriers and the transition from 28 national markets to one single market. It is estimated that this could annually bring EUR 415 billion to the European Union economy, which would inevitably reflect in the creation of new jobs (European Commission, 2018).

\subsubsection{Internet and media convergence}

The Internet, by and large, had the greatest role in accelerating media convergence and, more importantly, each new piece of knowledge is not followed by a period and is not exhausted with an invention, on the contrary this discovery serves as the basis for a new one. After all, computers, mobile phones and other online viewing platforms, functioning according to the allin-one principle, also serve as cameras, voice recorders, video cameras, calculators, notebooks reminders, etc.

Great efforts are being made at implementing information technologies in Europe and, according to 2017 indicators, Scandinavian countries, Great Britain, the Netherlands and Iceland lead the way with Albania, Bulgaria, 
Turkey and Montenegro significantly lagging behind the rest (Internet World Stats, 2018.).

China has 772 million Internet users, which is almost the entire population of Europe. A total of 53.2 percent, of the 1.4 billion Chinese, use the Internet.

During their annual holiday, the 2017 Chinese lunar New Year, 6.15 million Chinese traveled abroad, a 7\% increase compared to the same period in 2016 (China.org.cn, 2018).

Indicators of an increasing number of Chinese tourists traveling abroad are gaining in importance in the Republic of Serbia, especially after visa liberalization.

With increasing technological advancements, the media in India has developed a new aspect to digitizing content. Media convergence is based on three approaches: computer and Internet usage, communications with unique interactivity and text content, sound and video or multimedia (Vashishta, Negi, 2013).

Viewed globally, Singapore has gone the farthest with the convergence of television and the Internet, and has the highest penetration rate of smartphones in the world standing at $74 \%$. It is followed by Hong Kong 73\% and United Arab Emirates - 64\% (Infocomm Media Development Authority, 2012).

Through secured interactivity, an individual (reader, listener, viewer) ceases to be only a passive user of media content.

The first online edition was launched in 1992 by the daily paper The Chicago Tribune. Soon, the CNN television network created a website and the following seven years saw 3,600 digitals paper versions (Gocini, 2001). As is to be expected, these online editions were identical to the printed versions at the beginning, but this period did not last long, given continuous news updates, interactivity and hyperlinks which appear as imperatives to survival.

\subsubsection{Internet users in the European Union}

In 2017, the mobile broadband network was used by four out of ten households in the European Union, while $87 \%$ of households had Internet access, a notable increase from $70 \%$ in 2010 . This share is somewhat higher for households in urban areas (90\%) compared to rural areas (82\%). In 2017, most households (85\%) had broadband Internet. 
Among EU Member States, the largest share of users who access the Internet via a mobile/smartphone were identified in Spain (93\%), Cyprus (88\%) and the Netherlands $(88 \%)$. An important indicator is that almost all younger users of the Internet are from 16-24 years of age (94\%), and similar results are found for the 25-34 age group (91\%). The smallest number of Internet users being in the 65-74 age group (48\%).

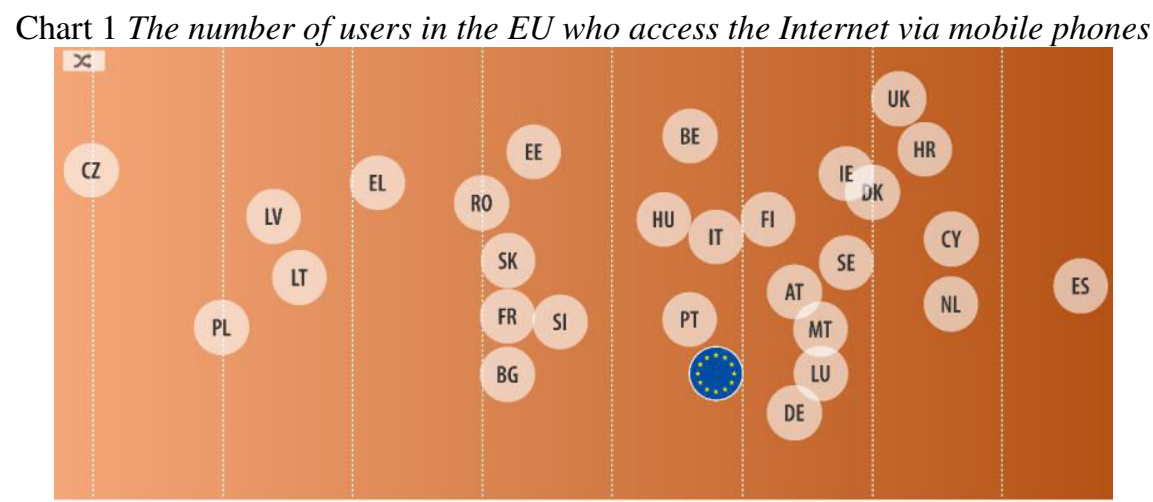

Source: https://ec.europa.eu/eurostat/cache/infographs/ict/2018/bloc-1a.html (November 06, 2018)

Many companies use the Internet during their daily activities, which is confirmed by the fact that at the beginning of 2017, only $3 \%$ of business subjects in the European Union did not have the Internet. In this respect, the most prominent problem is in Romania (15\%) and Greece (13\%). (European Commission, 2018).

\subsubsection{Internet users in Serbia}

In 2016, the Republic Institute of Statistics conducted a survey on the use of information and communication technologies in the Republic of Serbia, a two-phase sample of 2,400 households and 2,400 individuals, while the survey of 1,673 enterprises was conducted on a sample stratified according to size and activity.

The target group in market differentiation, compared according to the criteria "Household computer possession", was within the $65.8 \%$ range, an increase of $1.4 \%$ compared to 2015 . Differences were identified when comparing the representation of computers in urban and rural parts of Serbia: $73.3 \%$ versus $54.0 \%$. Compared to 2015, this gap has increased slightly. 
THE IMPACT OF MEDIA CONVERGENCE ON THE DEVELOPMENT OF INTEGRATED CORPORATE COMMUNICATION IN TOURISM

Chart 2 Percentage of households with an Internet connection, according to settlement type

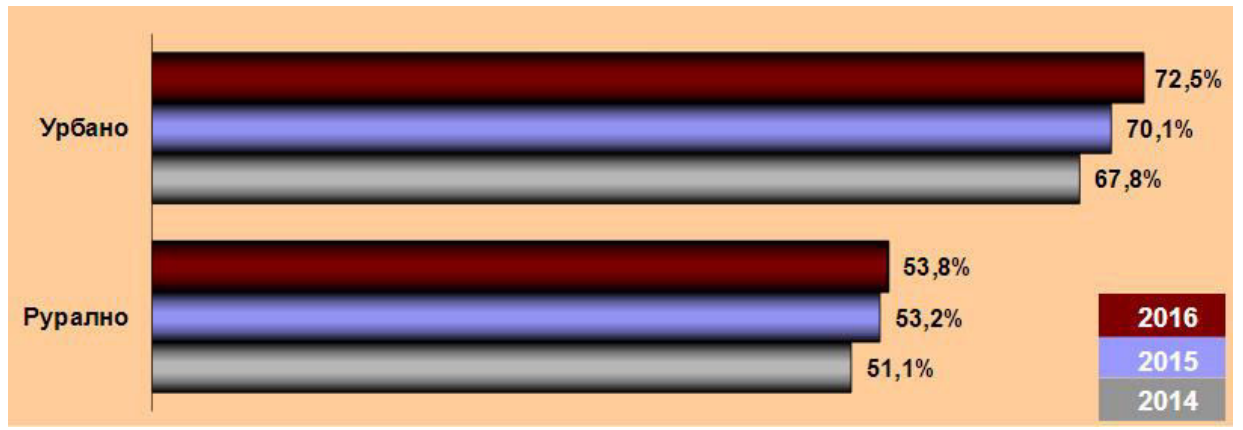

Source: www.stat.gov.rs/WebSite/repository/documents/00/02/25/86/IKT_2016_pres_s.pdf (January 05, 2018)

In addition, according to the same source, $64.7 \%$ of households own an Internet connection, which leads to the conclusion that this is the target group for the promotion of tourism products through convergent media. The largest share of Internet connections is in Belgrade $(73.1 \%)$, followed by the Autonomous Province of Vojvodina (68.7\%), with the smallest number of connection being in central Serbia (57.9\%).

The multiyear trend in the increase of Internet access via mobile phones, or a reduction in the number of households accessing the Internet through personal computers, was, at the turn of 2016: as many as $76.5 \%$ of households accessed the Internet using mobile phones in 2016, 72.0\% used personal computers, and $49.3 \%$ used the laptop for this purpose.

For tourist activity, an important indicator is that the number of people who purchased or ordered goods/services via the Internet in 2016 increased by just over 230,000, compared to 2015. It should also be noted that $54.6 \%$ of Internet users have never bought/ordered goods/services via the Internet (Republički zavod za statistiku, 2017).

\subsection{Website}

A website can best be compared to a boat in turbulent waters. As it is an illusion that one can swim in an ocean in a desired destination, one needs a boat, thus for the media a website is a necessity. The answer to why this is so is in the fact that the website is where tourism companies, and the media, are identified, where they present their products-services, i.e., editorial policy, and what they have to offer to their target groups. A well-created and regularly updated website is the place where the widest audience can get information about what is being offered and what is optimal for them. 
It is usually said that a website never sleeps, which is an important observation since this erases all time and space boundaries. However, a website requires the selection of quality content, which will attract attention, be of interest, truthful and unambiguous. It seems that there is no alternative to the commitment that tourism companies and the media have to offer highquality content, as this is precisely what gives them positive promotion and credibility, which should be visible in the balance sheet.

Regular analysis of visits to presentations is of great importance in improving two-way communication between the company - the owner of the presentation and the consumer - the visitor of the presentation. Visitor statistics is a very important element in the analysis of the quality of a web presentation (Stankić, Krsmanović, 2011).

The future of integrated tourism corporate communication is a readiness to create simultaneous messages for multiple media, which in turn means that managers in charge of corporate public relations should be ready to transmit the same content over the radio, television, print and the Internet, taking into account the specific requirements of each mentioned media.

The observed trends point to new conditions that are the result of novelties in the audiovisual industry due to digitization and convergence, and that is why new conditions are being posed before experts in integrated corporate communication in the tourist industry: investing in necessary multidisciplinary knowledge and developing multitasking skills, i.e., the efficient resolution of multiple tasks at once.

Due to an insufficient ability to follow observed trends, tourism companies seeking to create an expected corporate image and reputation, on the one hand, and employers in the media industry, on the other hand, cannot recruit enough trained personnel, possessing necessary knowledge, who are capable of applying it independently in a business environment. Media convergence creates new tasks for professionals in charge of integrated corporate communication in tourism as they are expected to write and distribute press releases, design them for the web and social networks, download dozens of high-quality photographs and mount video clips. In fact, the necessary knowledge and skills of practitioners in integrated tourism corporate communication are determined by the needs of the media and the expectations of the users.

The development of the Internet has led to radical changes in traditional communication and, taking into account the new circumstances in which users became content creators, the role of managers for integrated corporate 
communication and journalists has been transformed, i.e., "gatekeepers" who shape the news.

The best confirmation that users no longer want to be simply observes, but active participants and creators, is found on the Internet. The Internet has evolved from a platform where users were observers to a level characterized by exceptional interactivity. In view of this, it is clear that multimedia does not have observers like other media, but users who create their user content with their activities (Starčević, 2006).

Considering that the main product of interactive web production is multimedia content, managers of integrated tourism corporate communication are expected to know the specifics of writing and editing on the web, apart from the application of traditional principles.

The difference can be noticed as early as the title: while in traditional media the title should attract attention, the web insists on simplicity and informativeness, which means it must contain a key, or key words. Also, a web reader's attention is much shorter from that of a print reader's, suggesting that there is little chance that an average reader will open up a text if he/she does not recognize something that interests him/her in the title.

When writing for the web, what must be taken into account is that the text needs to be as clear as possible, while the more important parts of the text should be in bold or otherwise visually emphasized.

It should also be noted that print media is limited by the number of characters, and that it is realistic to expect that one or two photographs will be published along with the text. To the web, these restrictions are virtually unknown, while important events can be tracked through a photo gallery or by viewing video clips.

In addition to the fact that corporate communication managers are expected to have good knowledge of media relations' strategies and information-sharing techniques, common one-way communication has been replaced by interactivity, i.e., two-way communication, with the transfer to Web 2.0.

Web 2.0 encourages the tendency to find participants/users with the same interests and/or intentions, because this is a principle of exchange that relies on interconnection, on voluntary participation, often with an orientation towards a particular person (Andevski, Arsenijević, 2014). 
It is also necessary to point out the increasing importance of user-generated content, that is, content created by users other than journalists/photojournalists/cameramen. Namely, the development of the Internet has opened up the issue of the media's inability to write and report on a growing number of topics, and this is especially true during natural disasters or major accidents. The fact is that reporters are not able to be on the spot right way, and as an increasing number of citizens has cameras and video cameras this has opened the door for sharing content and information on social networks, even in real time. In addition, the insufficient number of journalists who can report and affirmatively write about business success, or socially responsible business of tourism companies, can be transformed into a chance, by proactive action, through regularly sent press releases, accompanying photos and video clips.

It can be argued that new communication technologies are a diametrically different practice in which the audience informs the journalists in order for the professional journalists to inform the general public. In this way, citizen journalism gains on significance and the Internet is a continuous source of new stories. In such a relationship, civic-professional journalism, social networks such as Facebook and Twitter, act as filters of information hyperproduction (Demetreffy-Lančić, 2010).

When we present the same story, or a variation of the story, on a large number of media platforms, then we call it "transmedia storytelling" (Jenkins, 2006), or "cross-media circuit" (Bechmann Petersen, 2006). Today, the term has been reduced to "transmedia", defining the openness and circulation of media content between different platforms where subjects, formerly known as "audiences", are increasingly incorporated in the production of flows (Jansson, 2013). Therefore, it can be said that the difference between consumers and producers has been reduced when tourists produce media texts for other tourists in order to use and consume them. The production of such content and interactions is mostly done on the Internet (Williams, 2008).

A partnership relationship implies that the manager for integrated tourism corporate communication respects the basic principles of media relations: availability, professionalism, informativeness, affability and reliability.

In addition, it is necessary to insist on the use of simple linguistic forms in media communication, and much more so for radio and television programs than for print. This is justified from the point of view that more than half of the population in Europe uses two to three thousand words on a daily basis, while an average citizen with a completed elementary school education uses 7,000 words, in total. 
The linguistic aspect of media communication, implied by integrated corporate communication, should be subject to clarity and expressive unambiguousness, that is, it is unacceptable to "sacrifice" the idea and key message we are sending to an audience because of style or insistence on reverence for form.

\subsection{Print}

The growth of the audience and the growing influence of Internet media have resulted in a decrease in print media circulation. However, print media adapted to the new environment emphasizing analyticity as its comparative advantage.

Nearly all newspapers, dailies and periodicals, have their content on Internet portals. As a rule, the topics offered are those published in printed editions, but they also feature additional content such as photo galleries, video and audio recordings.

The photograph has, over time, acquired the reputation of a witnesses to numerous historical and other events and personalities, whose testimony does not always have to be credible, primarily because of the possibility of photo editing. It is important for tourism workers to know that people are more inclined to believe in the truthfulness of message content sent in the form of a printed text than through an immediate conversation (Isaković, 1991).

Circulation of printed editions declines drastically by the day, and media are increasingly turning to online editions. Print media have their own Internet portals, and despite the fact that part of the reading audience has expressed dissatisfaction over the "extinction" of print media and the rapid transition to a wider platform, it is an unstoppable and irreversible process. When the fact that free circulation dailies has more than doubled over the past five years, reaching 40.8 million copies, is added to this market environment, then the diagnosis becomes additionally aggravating. Many claim that free newspapers are the most serious threat and challenge to classic newspapers, after the Internet (Rutović, 2009).

For print media, it is also important to better evaluate the attention the reader intends to devote to a newspaper product, within a single linguistic area. The maximum time a reader allots to reading a specific piece of news, without the scattering of attention, oscillates between 30 and 90 seconds, after which attention is automatically diverted to another text. On average, during that time, the reader reads about 300 words, or 1,800 characters (Bešker, 2004). 
In a dynamic and interactive environment, with a still undefined legal framework for so-called citizen journalism, the role of the integrated function for the development of tourist corporate communication gains on importance primarily due to expressed credibility.

\subsection{Radio}

In comparison to print media, it is a young media: taking on the form it has today in the 1920s. When simply looking at the number of radio stations broadcasting programs and the number of receivers, followed by population coverage, radio is considered to be the most influential means of mass communication.

Radio's comparative advantage, of note, is that it is the fastest and most informative means of public communication, it does not require time, i.e., it may be listened to while doing other things. Radio is a powerful expressive agent, while at the same time being the most economical means of public communication, of diverse content.

Radio stations have their own websites and an ever-increasing quantity of content is uploaded to be complemented with text, photos and videos.

Unlike other media, radio stations are unique in relation to the necessary activities undertaken by integrated tourism corporate communication. Positive corporate publicity can be formed, this is not in dispute, but it is also necessary to list factors that cannot always influence expected results. For example, it is not possible to control the place where the program is being heard, because it could be anywhere: at home or at work, in a car, on a beach or the playground, on a street, or just about anywhere else in world. Also, it is not possible to influence the product - the program, because it is conditioned by more events than simply management's decisions. On a somewhat broader perspective, from the viewpoint of marketing integration and public relations, it is necessary to point out the lack of influence on the price of the program, because radio listening is free, as well as on post-sales services, which are mostly reduced to listener complaints (Bakman, 2004).

The attention span of a radio audience while listening to the news is no longer than 90 seconds but it is subject to change, depending on the media. On average, a journalist can clearly say 120 to 140 words of a prepared text, in one minute (Bešker, 2004).

The attention span depends on the information itself, as well as the journalistic genre. For more extensive footage, it is necessary to keep the listener's attention, at first contact, with no more than ten lines of spoken, or 
thirty lines of printed, text. This means that distributed communication on events and company products cannot step out of the mentioned temporal, and spatial, frameworks.

\subsection{Television}

Television, as a medium of mass communication, enjoys, without a doubt, great coverage and a wide audience while the introduction of specialized channels segments the targeted audience. The ability of a television message to reach a million viewers, at the same moment, is one of its most important features.

Despite the development of information technology and the emergence of new media, television is the most important source of information for the greatest number of people. As much as 98 percent of Europe's residents have a television set and watch more than 200 minutes a day. With the advent of the Internet and online multimedia platforms, television has not automatically lost its viewers, but it is gradually starting to. Television is mostly "losing" audiences between 16 and 24 years of age (Car, 2007).

The Internet is not a threat to television, nor to radio and print, but it should be viewed through an integrative prism. Namely, the differences could persist until video content was an obstacle to Internet capabilities. However, the development of new video content platforms has solved the problem of too much video content, and since then it has been possible to talk about the Internet and television permeating.

The integrative function of the Internet and television has opened up numerous opportunities for enhancing integrated corporate communication, in particular by appreciating interactivity that offers the ability to adapt, not only to a proactive media relationship, but also by lowering the scale to a personal communication level.

The inevitable product of media trends and an increasingly frequent focus on the individual has posed yet another challenge, for managers in charge of integrated tourism corporate communication, visible through the fragmentation of television viewers, i.e., target audiences. Segmented audiences are less and less interested in the general programming content offered by television, and more and more interested in specialized programs. As new technologies accelerate and dictate new operating methods, it is realistic to expect that in the future the function of integrated tourism corporate communication will be more strongly exposed to technological, organizational and structural variables. 
Although, in the future, there will be those individuals and groups who cannot, or do not want, to follow innovation trends and thus, determine for themselves what to look at, when and where, it is realistic to expect the retention and updating of each new medium, and not its replacement (Noriss, 2000).

As bearers of various communication forms, the media did not remain immune to the development of new communication technologies. In spite of the fact that new communication technologies have a powerful influence on the established forms of communication, forcing them to change, it should be emphasized that the media are changing, adhering, but not disappearing (Fidler, 2004). On the contrary, through the acceptance and implementation of new technological characteristics, coexistence and convergence are visible, imposing the conclusion that it is not realistic to expect the disappearance of any communication medium.

\subsection{Social media}

Social media are free online services that allow users to represent themselves personally, and to communicate. These are media that integrate modern Internet technologies and users in a quick and easy manner. If we view them as a channel of online communication, we see that Web 2.0 technology is its basis.

Social media can also be defined as online resources and platforms that people use to share their views, perceptions, experiences and perspectives (Kostić - Stanković, 2011). In practice, it is not uncommon to equate social media and social networks, which is untrue. Social networks or social networking websites are actually profile-oriented websites that encourage users to socialize and establish relationships (Starčević, Štavljanin, 2013).

Although the most visible, social networks are but one segment of the social media set. If viewed by name, it can be concluded that social networks are intended for socializing, and today they are more intensively used then even e-mail (Radović, 2010).

The advantage of social media is reflected mostly through audience feedback, as well as the easier targeting of key messages towards target groups. The emphasis in everyday activities is not only on what the companies convey to the audience, but on the feedback they receive so as to learn, on time, what it is the audience wants.

Apart from individuals, companies are becoming more present on social networks, opening up their own websites, i.e., profiles, forming so-called fan 
pages or groups, and setting up advertisements that appear on profile pages of individual users and which, in addition to the text contain a picture of a product or service (Đorđević et al. 2014).

Increased use of smartphones and mobile devices has opened up the possibility of mobile social networks with an increased number of features. In addition, most social networks are also available as social applications for mobile devices, while some networks are optimized for searching mobile Internet, enabling users to access visual blogging sites.

Chart 3 Number of global social network users from 2010 to 2021 (in billions)

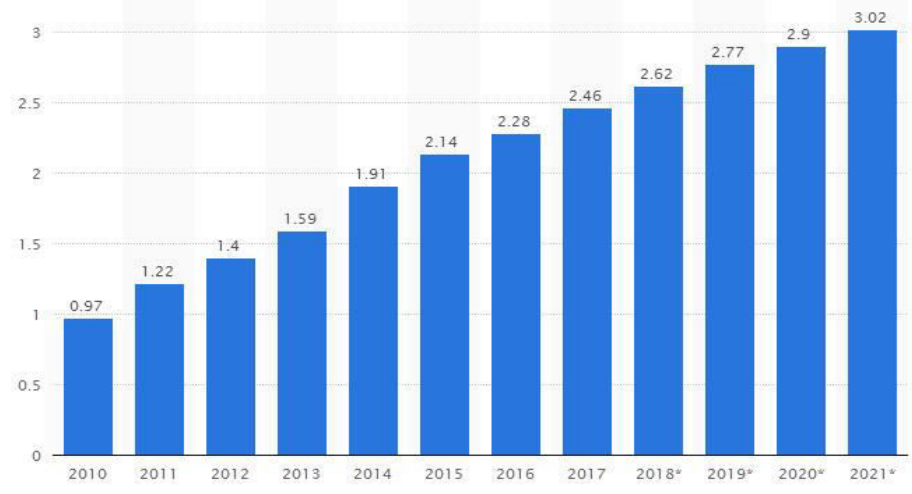

Source:https://www.statista.com/statistics/278414/number-of-worldwide-social-networkusers/(October 01, 2018)

For the functioning of integrated tourist corporate communication, it is important that companies, utilizing social networks, secure respectable corporate publicity, as well as enviable external and internal communication. The particularity of social networks is not only that it enables getting to know new people, but also that it makes an individual's social life visible to already known people. By analyzing data from individual profiles, or by selecting a company's page, segmenting the public can be significantly accelerated and simplified. It is also important to know about the existence of a code that is binding to social media, since it ensures actions in suppressing rumors and the spreading of inaccurate information that could endanger the acquired image and reputation.

In the traditional confrontation between two extremes, between the long-term development function strongly generated by integrated tourism corporate communication, and short-term economic interests, organizations need a high-quality, well-planned and organized strategy based on employee knowledge and skills, a key condition for further development. 


\section{CONCLUSION}

Media convergence is a dynamic process that is reflected in the permeation and integration of various media, which influences the organization of tourist activities, media content and its distribution, as well as changing the habits and roles of consumers - tourists and media consumers.

Media convergence is presented as a process, the emphasis being on the technological, economic, social, cultural and global impact it has on traditional media, as well as on web and mobile content. These are basic determinants that influence the planning and formation of corporate culture, identity, image and reputation, with the aim of the desired positioning of an organization, i.e., its public competitive positioning.

The significance of the topic is visible in the trends that support further integration of tourism and media industries, which gives a desirable synergistic effect.

This leads to an unequivocal conclusion that the mutual promotion and exchange of tourist content is the basis on which a sustainable media convergence is built.

Convergence has irreversibly changed mass media, as well as the function of integrated tourism corporate communication. The convergence process fundamentally changes tourism business functions, since in the past the media were viewed and studied as separate platforms, and now, thanks to information technology, there is a need for a different approach and interpretation of their role and importance based on the combination of several connected platforms.

Media convergence is a process subject to constant quantitative and qualitative changes, which is the direct result of adjusting and changing the function of integrated tourism communication at the organizational level.

\section{REFERENCES}

1. Andevski M., Arsenijević J. 2014. Konvergencija u kontekstu Web 2.0 - pedagogija navigacije. 12. međunarodna naučno-stručna konferencija Doba znanja. Sremski Karlovci

2. García Avilés, J.A., Meier, K., Kaltenbrunner, A., Carvajal, M. and Kraus, D., 2009. Newsroom integration in Austria, Spain and Germany: Models of media convergence. Journalism Practice, 3(3), pp.285-303. 
3. Bakman, Dž. et. al. 2004. Promocija i marketing elektronskih medija. Beograd: Clio.

4. Blek, S., 2003. Odnosi s javnošću. Beograd: Clio.

5. Petersen, A.B., 2006. Internet and cross media productions: Case studies in two major danish media organizations. Australian Journal of Emerging Technologies \& Society, 4(2).

6. Bešker, I., 2004. Istraživačko novinarstvo. Zagreb: PressData.

7. Car, V. (2007). Konvergirani javni medijski servis. Zagreb: Politička misao.

8. Demeterffy Lančić, R., 2010. Novi mediji i odnosi s javnošću, Medijske studije (157-169).Zagreb.

9. Đorđević, A., Kostić - Stanković, M., Cvijović, J.. 2014. Uporedna analiza oglašavanja putem tradicionalnih i društvenih medija. Novi ekonomist. 15, Bijeljina.

10. Fidler, R., 2004. Mediamorphosis - razumevanje novih medija. Beograd: Clio.

11. Gocini, Đ., 2001. Istorija novinarstva. Beograd: Clio.

12. Isaković, Z., 1991. Uvod u propagandu. Beograd: Zavod za udžbenike i nastavna sredstva.

13. Jansson, A., 2013. Mediatization and social space: Reconstructing mediatization for the transmedia age. Communication Theory, 23(3), pp.279-296.

14. Jenkins, H., 2001. Convergence? I diverge. Technology review, 104(5), p.93.

15. Jenkins, H., 2006. Convergence Culture. Where Old and New Media Collide. New York, London: New York University Press.

16. Kalamar, D., 2016. Convergence of media and transformation of audence, Informatol. 49, pp. 190-202.

17. Kostić-Stanković, M., 2011. Integrisane poslovne komunikacije. Beograd: Fakultet organizacionih nauka.

18. Kostić-Stanković, M., Todović, D., 2015. Integrisanje korporativnih komunikacija u razvoju poslovnog komuniciranja, Zbornik radova, $X$ Skup privrednika i naučnika SPIN, Fakultet organizacionih nauka, Beograd.

19. Martinoli, A., 2011. Konvergencija i digitalizacija medija-nove uloge publike i medija. Medijski dijalozi, 9, pp.71-91.

20. Norris, P., 2000. A virtouous Circle: Political Communications in Postindustrial Societies. New York: Cambridge University Press.

21. Radović, N., 2010. Društvene mreže u veb-novinarstvu. Priručnik Veb novinarstva. Beograd: Udruženje novinara Srbije.

22. Ramonet, I., 2001. La tyrannie de la communication (The Tyranny of Communication). Paris: Gallimard.

23. Rutović, Ž., 2009. Kriza štampe, Matica, god. 10, No. 40, str. 49-66. 
24. Stankić, R., Krsmanović, B., 2007. Elektronsko poslovanje. Bijeljina: Fakultet spoljne trgovine.

25. Starčević D. (2006). Digitalna ekonomija, Fakultet organizacionih nauka, Beograd

26. Starčević D., Štavljanin V. (2013). Multimediji, Fakultet organizacionih nauka, Beograd

27. Vashishta, S., Negi, N., 2013. Convergence in Indian media: A new Paradigm of ICT, [online] Available at: <https://www.researchgate.net/publication/294863425_CONVERGENC E_IN_INDIAN_MEDIA_A_NEW_PARADIGM_OF_ICT> [Accessed 28 September 2018]

28. Williams, B., 2008. "What South Park character are you?": popular culture, literacy, and online performances of identity. Computers and Composition, 25(1), pp.24-39.

29. Word Travel \& Tourism Council (WTTC), 2018. Travel \& Tourism Economic Impact 2018 Serbia. [pdf] London: WTTC. Available at: $<$ https://www.wttc.org/-/media/files/reports/economic-impactresearch/countries-2018/serbia2018.pdf> [Accessed 28 September 2018].

30. European Commission, 2018. Digital single market. [online] Available at: <https://ec.europa.eu/commission/priorities/digitalsingle-market_en> [Accessed 25 October 2018].

31. Internet World Stats, 2018. Internet in Europe Stats. [online] Available at: <https://libweb.anglia.ac.uk/referencing/harvard.htm> [Accessed 25 October 2018].

32. China.org.cn, 2018. $6.5 \mathrm{mln}$ Chinese to travel overseas during Spring Festival holiday. [online] Available at: <http://www.china.org.cn/travel/2018-02/03/content_50399374.htm> [Accessed 01 May 2018].

33. Infocomm Media Development Authority, 2012. Media convergence review final report. [pdf] Available at: <https://www.imda.gov.sg//media/imda/files/regulation-licensing-andconsultations/consultations/media-convergence-review/1-mediaconvergence-review-final-report.pdf?la=en> [Accessed 03 May 2018].

34. Republički zavod za statistiku, 2017. Upotreba informaciono komunikacionih tehnologija u Republici Srbiji, 2017. [pdf] Available at:<http://publikacije.stat.gov.rs/G2017/Pdf/G20176006.pdf> [Accessed 05 January 2018].

Received: 16 November, 2018

Accepted: 22 December, 2018 